\title{
THE USE OF MOLASSES AS ADDITIVE WITH DIFFERENT ENSILING TIME AND PHYSICAL QUALITY, pH AND NUTRITIVE OF VALUE MAIZE STOVER SILAGE
}

\author{
Hartutik $^{1)}$, Marjuki ${ }^{1)}$, Asri Nurul Huda ${ }^{1)}$, Poespitasari Hazanah Ndaru' ${ }^{1)}$, Yuanita Nur Arsianty ${ }^{1)}$, \\ Binti Nur Rohmah ${ }^{1)}$ \\ ${ }^{1)}$ Faculty of Animal Science University of Brawijaya, East Java, Indonesia, 65145 \\ Email: hartutik@ub.ac.id
}

\begin{abstract}
The objectives of this experimental research was to determine the effect of different ensiling time of maize stover silage with molasses as additive on physical quality, $p H$ and nutritive value. The experiment used Factorial Randomized Completely Design (RCD) of two factors (maize stover $=A$ and maize stover $+10 \%$ molasses $=B), 3$ ensiling time $(0,7,14$ days) and 4 replications. The treatments consisted of ( $A_{0}=$ maize stover without incubation, $A_{1}=$ maize stover incubated for 7 days, $A_{2}=$ maize stover incubated for 14 days $)$ and $\left(B_{0}=\right.$ maize stover $+10 \%$ molasses without incubation, $B_{1}=$ maize stover $+10 \%$ molasses incubated for 7 days, and $B_{2}=$ maize stover $+10 \%$ molasses incubated for 14 days). The variable was measured physical quality, $p H$ and nutritive value. The results showed that incubation time of $A$ and $B$ gave significant effect on physical quality and $\mathrm{pH}$ silage, maize stover silage without and with $10 \%$ molasses incubated 14 days gave the best result of physical quality and $\mathrm{pH}(\mathrm{A}=4.00$ and $B=3.89)$ silage. The result showed that incubation time of $A$ and $B$ gave highly significant effect $(P<0.01)$ on Dry Matter $(D M)$ and Ether Extract $(E E)$, however it did not give significant effect $(P>0.05)$ on Organic Matter $(O M)$. It can be concluded that maize stover silage with $10 \%$ molasses incubated for 14 days could increase physical quality, decreased $\mathrm{pH}$ and maintain nutritive value.
\end{abstract}

Keywords : Maize stover, molasses, physical quality, $\mathrm{pH}$ and nutritive value

How to Cite:

Hartutik., Marjuki., Huda A. N., Ndaru P. N., Arsianty Y. N., \& Rohmah B. N. (2021). The Use of Molasses as Additive with Different Ensiling Time and Physical Quality, $\mathrm{pH}$ and Nutritive of Value Maize Stover Silage. Jurnal Nutrisi Ternak Tropis 4 (2) 88-92
*Corresponding author:

Hartutik

Email: hartutik@ub.ac.id

Faculty of Animal Science University of Brawijaya,

East Java, Indonesia, 65145 


\section{INTRODUCTION}

Maize stover is part of a corn plant that is two month old before corn is harvested. The maize stover contains CP of $12.06 \%$, CF $23.3 \%$, Ca $0.25 \%$ and $\mathrm{P} 0.23 \%$ (Htet et al., 2016) the availability of maize stover is abundant during the rainy season, so that excess maize stover can be stored and using during the dry season. One of the preservation technologies that can be used to preserve fresh maize stover is silage. Making silage is one of the forage preservation strategies to overcome the shortage of forage during the dry season. The principle of making silage is to use anaerobic fermentation techniques and $\mathrm{pH}$ $<4$. The success of the silage making process is to achieve stable silage conditions as quickly as possible namely an-aerobic conditions and $\mathrm{pH}<4$.

The addition of molasses as a Water Soluble Carbohydrate (WSC) can be done in making silage to support the activity of lactic acid bacteria in order to produce organic acids that are useful for lowering the $\mathrm{pH}$ in making silage. The use of monosaccharides such as glucose and fructose can accelerate the decrease in $\mathrm{pH}$ resulting in the accumulation of lactic acid (Santoso et al., 2009). The ensilage process begins with the microbes that break down the nutrients contained in the silage material through the fermentation process under aerobic conditions. Aerobic fermentation will end if the oxygen in the silo is exhausted, then the condition becomes anaerobic and the aerobic microbes begin to actively decompose food substances, especially carbohydrates into lactic acid. Molasses has $>40 \%$ WSC content which provides fermentation substrate for Lactic Acid Bacteria during ensiling (Lima et al., 2010).

Silage making is ideally ensiling for 21 days but if the ensilage process can reach a stable condition faster before 21 days it would be better. The aim of this research is to determine the making of corn sugarcane silage by adding $10 \%$ molasses with incubation time of 0,7 and 14 days.

\section{MATERİAL AND METHOD}

\section{Experimental Materials and Design}

Fresh maize stover was harvested at 45-65 days from cropland in Malang City, East Java Province, Indonesia. The fresh maize stover samples harvested in the morning were used to prepare silage. The maize stover treated with and without molasses then mixed thoroughly prior to ensiling. For the maize stover, commercial molasses was added in proportion $10 \%$ (fresh weight). The experiment consisted of 6 treatments:

$\mathrm{A}_{0}=$ maize stover without ensilation

$\mathrm{A}_{1}=$ maize stover ensiled for 7 days

$\mathrm{A}_{2}=$ maize stover ensiled for 14 days

$\mathrm{B}_{0}=$ maize stover $+10 \%$ molasses without ensilation

$\mathrm{B}_{1}=$ maize stover $+10 \%$ molasses ensiled for 7 days

$\mathrm{B}_{2}=$ maize stover $+10 \%$ molasses ensiled for 14 days

To make silage, the maize stover material was chopped into lengths of about 2 to $5 \mathrm{~cm}$. Approximately $1.2 \mathrm{~kg}$ of both maize stover with and without molasses was placed in plastic jar (3.5 liter), the top of jar warped with plastic wrap and then stored in dark place. After 7, 14 and 21 days of ensiling, representative samples were removed for further chemical analysis, $\mathrm{pH}$ analysis, and physical qualities following and adapted from (Mustika and Hartutik, 2021).

\section{Chemical analysis}

Dry matter, crude ash, crude protein $(\mathrm{CP})$, crude fiber $(\mathrm{CF})$, and ether extract (EE) contents of samples were measured following Association of Official Analytical Chemists (AOAC) (2005) methods. 


\section{pH and physical characteristic}

Physical characteristics analyses conducted on silage sample using color, flavor, texture, the presence of molds. Determination of $\mathrm{pH}$ was using a $\mathrm{pH}$ meter, and distilled water was added to samples in a ratio 10:1 and $\mathrm{pH}$ can recorded (Nahm, 1992).

\section{Statistical analysis}

The data on nutrient composition and $\mathrm{pH}$ were analyzed using analysis of variance with Factorial Completely Randomized Design. The experimental design consist of 2 factors and 4 ensiling time and also 4 replications each factor. Physical quality data was analyzed by using descriptive analysis.

\section{RESULT AND DISCUSSION}

\section{Physical Quality and pH}

The physical quality of the silage are shown in Table 1. Maize stover silage without molasses and maize stover silage with adding 10\% molasses had different color, aroma and texture at ensiling time 7 , 14 and 21 days. Table 1 shows that maize stover silage with and without the addition of $10 \%$ molasses caused differences in color, flavor and silage texture, both in incubation of 7, 14 and 21 days. Maize stover silage with $10 \%$ molasses and 21 days ensiling times produces the best color, flavor and texture, which has a yellowish green color with a slightly acidic flavor, soft texture and no fungus. According to Rahayu et al. (2017) good silage has a yellowish green or brownish green color and the silage's flavor was fresh acid as a characteristic of high lactic acid and the decay that causes silage smells of butyric, silage has a dense and soft texture and is not slimy and moldy. Treated silage has fragrant flavor compare to the control silage and silage without inoculant and WSC showed the worst flavor compare with others (Sofyan et al., 2017; Mustika and Hartutik, 2021).

This is in accordance with the opinion of Despal et al. (2011) which states that silage given molasses has a slightly moist texture so that it is in accordance with ideal conditions for bacterial growth. The palatability was influenced by taste, texture and also flavor (Sofyan et al., 2017). The result showed that silage with $10 \%$ molasses addition with 21 days ensiling times more palatable than others.

Table 1. Physical Quality of Silage

\begin{tabular}{lccccc}
\hline \multirow{2}{*}{ Sample } & Ensiling & \multicolumn{4}{c}{ Parameters observed } \\
\cline { 3 - 6 } & Time (Days) & Color & Flavor & Texture & LFC \\
\hline Maize Stover & 0 & Fresh-Greenish & Fresh & Hard & Absent \\
Silage & 7 & green-browning & Moderately acidic & Slightly soft & Absent \\
& 14 & green-browning & Slightly acid & Slightly soft & Absent \\
& 21 & green-browning & Slightly acid & soft & Absent \\
\hline Maize Stover & 0 & Light yellow, a & Fresh moderately & Hard & Absent \\
Silage + 10\% & 7 & little bit greenish & sweet & & Absent \\
Molasses & 14 & green-browning & Moderately acidic & Slightly soft & Absent \\
& 21 & green-browning & Slightly acid & soft & Absent \\
\hline
\end{tabular}

LFC: Level of Fungal Contamination

Table 2 shows that the maize stover silage treatment without molasses addition had the lowest $\mathrm{pH}$ at 21 days ensiling time at 4.00 compared to 0 days i.e. 5.81, 7 days at 4.13 and 14 days at 4.02. Whereas maize stover silage with the addition of $10 \%$ molasses had the lowest $\mathrm{pH}$ at 14 days incubation at 3.89 compared to 0 days at 5.67, 7 days 4.92 and 21 days 4.25. The decrease in $\mathrm{pH}$ is due to an increase in the number of lactic acid bacteria so that lactic acid increases. In the treatment of maize stover with $10 \%$ molasses with 14 days ensiling, the optimum $\mathrm{pH}$ (acid) was 
reached, which was 3.89. This happens because the Water Soluble Carbohydrate available (WSC) in maize stover was sufficient for the growth of lactic acid bacteria. Lactic acid bacteria are main key in succeed for fermentation process (Kung et al., 2018; Sjofjan et al., 2021; Sjofjan and Adli, 2021). The low $\mathrm{pH}$ from lactic acids killing the microbes intolerant to the low $\mathrm{pH}$ and also stabilize the fermentation process (Kung et al., 2018).

Table 3 shows that maize stover silage with and without $10 \%$ molasses addition had a very significant effect $(\mathrm{P}<0.01)$ on $\mathrm{OM}$ and $\mathrm{CP}$, but had no significant effect $(\mathrm{P}>$ $0.05)$ on DM, CF and EE. Maize stover silage using $10 \%$ molasses with 14 days ensiling time was the best treatment, indicated by the low $\mathrm{pH}$ and $\mathrm{CF}$ values of 3.98 and $26.84 \%$ respectively and high OM and CP values of $7.98 \%$ and $9.95 \%$ respectively.

The optimal ensiling time for microbial growth was 14-days in the process of microbial degraded lignin, so that cellulose and hemicellulose in forage can be used as the main energy source for ruminants. The presence of lignin will reduce the digestibility of carbohydrates through the formation of hydrogen bonds on the critical side, thereby limiting the activity of cellulase enzymes. Crude fiber is a factor that affects digestion. In general the lower the SK the higher the digestibility and the rate of degradation of feed ingredients in the rumen (Rahayu et al., 2017).

Table 2. Power of Hydrogen ( $\mathrm{pH}$ ) Silage

\begin{tabular}{lcccc}
\hline \multirow{2}{*}{ Sample } & \multicolumn{4}{c}{ Ensiling Time (Days) } \\
\cline { 2 - 5 } & 0 & 7 & 14 & 21 \\
\hline Maize Stover Silage & $5.81^{\mathrm{c}}$ & $4.13^{\mathrm{bc}}$ & $4.02^{\mathrm{b}}$ & $4.00^{\mathrm{a}}$ \\
Maize Stover Silage $+10 \%$ Molasses & $5.67^{\mathrm{c}}$ & $4.92^{\mathrm{bc}}$ & $3.89^{\mathrm{a}}$ & $4.25^{\mathrm{b}}$ \\
\hline
\end{tabular}

Different superscript in same column or row showed a significant difference $(p<0.05)$

Table 3. Chemical Composition of Silage

\begin{tabular}{lccccccc}
\hline \multirow{2}{*}{ Sample } & \multirow{2}{*}{ Time (Days) } & \multirow{2}{*}{ DM $(\%)$} & \multicolumn{5}{c}{ Nutritive Value (\% DM) } \\
\cline { 4 - 7 } & & OM & Ash & CP & CF & EE \\
\hline Maize Stover & 0 & 27.24 & $7.07^{\mathrm{c}}$ & 92.93 & $10.05^{\mathrm{a}}$ & 29,06 & 1.58 \\
Silage & 7 & 26.92 & $6.73^{\mathrm{b}}$ & 93.27 & $14.32^{\mathrm{c}}$ & 28.84 & 2.35 \\
& 14 & 27.75 & $6.85^{\mathrm{bc}}$ & 93.25 & $11.61^{\mathrm{bc}}$ & 28.35 & 2.03 \\
& 21 & 24.67 & $6.42^{\mathrm{a}}$ & 93.58 & $10.89^{\mathrm{b}}$ & 27.73 & 2.79 \\
\hline Maize Stover & 0 & 29.12 & $7.42^{\mathrm{b}}$ & 92.58 & $9.25^{\mathrm{c}}$ & 28.00 & 2.15 \\
Silage + 10\% & 7 & 28.57 & $7.63^{\mathrm{bc}}$ & 92.37 & $9.08^{\mathrm{a}}$ & 27.03 & 1.59 \\
Molasses & 14 & 27.24 & $7.98^{\mathrm{c}}$ & 92.02 & $9.95^{\mathrm{b}}$ & 26.84 & 1.92 \\
& 21 & 27.22 & $6.99^{\mathrm{a}}$ & 93.01 & $10.06^{\mathrm{bc}}$ & 26.55 & 2.50 \\
\hline
\end{tabular}

Different superscript in same column or row showed a significant difference $(p<0,05)$

The CP content of silage from maize stover using $10 \%$ molasses in 7 days ensiling time has decreased, this is indicated by the presence of bacteria, especially clostridia, which actively reforms proteins and produces ammonia. At week 2 (incubation 14 days) $\mathrm{CP}$ increases, this is caused by microbes that have good growth and breeding, so that it can change more constituent components originating from the microbial body itself which will increase the crude protein content of the substrate.

\section{CONCLUSIONS}

Maize stover silage with $10 \%$ molasses addition with 14 days ensiling time was the best treatment basd on $\mathrm{pH}$ and silage content. 


\section{REFERENCES}

AOAC. (2005). Official Methods of Analysis of the Association of Official Analytical Chemists. Association of Official Analytical Chemist.

Despal, D., Permana, I. G., Safarina, S. N., \& Tatra, A. J. (2011). Penggunaan berbagai sumber karbohidrat terlarut air untuk meningkatkan kualitas silase daun rami. Media Peternakan, 34(1), 69-76. https://doi.org/10.5398/medpet .2011.34.1.69

Htet, M. N. S., Than, N. N., Soomro, R. N., Ya-Dong, X., \& Jiang-Bo, H. (2016). Comparison of nutrients composition , forage and silage yields of maize (Zea mays L). Scholars Journal of Agriculture and Veterinary Sciences, 3(7), 474-479.

Kung, L., Shaver, R. D., Grant, R. J., \& Schmidt, R. J. (2018). Silage review: Interpretation of chemical, microbial, and organoleptic components of silages. Journal of Dairy Science, 101(5), 4020-4033. https://doi.org/10. 3168/jds.2017-13909

Lima, R., Lourenço, M., Díaz, R. F., Castro, A., \& Fievez, V. (2010). Effect of combined ensiling of sorghum and soybean with or without molasses and lactobacilli on silage quality and in vitro rumen fermentation. Animal Feed Science and Technology, 155(24), 122-131. https://doi.org/10.1016/ j.anifeedsci.2009.10.008

Mustika, L. M., \& Hartutik, H. (2021). Kualitas silase tebon jagung (Zea mays L.) dengan penambahan berbagai bahan aditif ditinjau dari kandungan nutrisi. Jurnal Nutrisi Ternak Tropis, 4(1), 55-59. https://doi .org/10.21776/ub.jnt.2021.004.01.7

Nahm, K. H. (1992). Practical Guide to Feed, Forage and Water Analysis.
Yoo Han Publisher.

Rahayu, I. D., Zalizar, L., Widianto, A., \& Yulianto, M. I. (2017). Karakteristik dan Kualitas Silase Tebon Jagung (Zea mays) Menggunakan Berbagai Tingkat Penambahan Fermentor yang Mengandung Bakteri Lignochloritik. Seminar Nasional Dan Gelar Produk.

Santoso, B., Haryadi, B. T., Manik, H., \& Abubakar, H. (2009). Kualitas rumput unggul tropika hasil ensilase dengan bakteri asam laktat dari ekstrak rumput terfermentasi. Media Peternakan, 32(2).

Sjofjan, O., \& Adli, D. N. (2021). The effect of replacing fish meal with fermented sago larvae (FSL) on broiler performance. Livestock Research for Rural Development, 33(2).

Sjofjan, O., Nur Adli, D., Djunaidi, I., \& Kuncoro, K. (2020). Utilization of Biogas Liquid Waste For Starter In The Fermentation of Rice Husk As A Potential Feed For Poultry. Animal Production, 22(1), 24-30. https:// doi.org/10.20884/1.jap.2020.22.1.38

Sofyan, A., Widyastuti, Y., Utomo, R., \& Yusiati, L. M. (2017). Improving physico-chemical characteristic and palatability of king grass (pennisetum hybrid) silage by inoculation of Lactobacillus plantarum Saccharomyces cerevisiae consortia and addition of rice bran. Buletin Peternakan, 41(1), 61-71. https://doi. org/10.21059/buletinpeternak.v41i1.1 2980

Sucu, E., \& Filya, I. (2006). The effects of bacterial inoculants on the fermentation, aerobic stability and rumen degradability characteristics of wheat silages. Turkish Journal of Veterinary and Animal Sciences, 30(2), 187-193. 